\title{
Firn-core study from the southern Patagonia ice cap, South America
}

\author{
Alberto J. Aristarain \\ Instituto Antártico Argentino and Consejo Nacional de Investigaciones Científicas y Técnicas, 5500 Mendoza, Argentina \\ Robert J. Delmas \\ Laboratoire de Glaciologie et Géophysique de l'Environnement, 38402 Saint-Martin-d'Hères Cedex, France
}

\begin{abstract}
A shallow firn core, recovered from the southern Patagonia ice cap (elevation $2680 \mathrm{~m}$ a.s.l.), has been analyzed for $\mathrm{H}$ stable isotope composition and for major soluble chemical compounds. The temperature measurement at $13.17 \mathrm{~m}$ depth (bottom of the core) shows that the ice cap is temperate. The chemical profiles indicate that some soluble impurities have been partly washed out by percolation, but seasonal deuterium content variations are relatively well preserved down to the bottom of the core, which allows the net accumulation rate of the site to be calculated $(1.2 \mathrm{~m}$ water equivalent). The mean concentrations measured in the most recent year recorded $\left(\mathrm{Cl}^{-}: 4.85\right.$, nss $_{4}{ }^{2-}: 0.65, \mathrm{NO}_{3}^{-}: 0.32, \mathrm{Na}^{+}: 4.30, \mathrm{~K}^{+}: 0.64$ and $\mathrm{NH}_{4}^{+}$: 0.77 , in $\mu$ eq. $1^{-1}$ ) serve as a reference for the background chemical composition of precipitation at mid-southern latitudes under South Pacific meteorological conditions.
\end{abstract}

\section{INTRODUCTION}

Snow accumulated in polar areas or on high mountains records environmental parameters, such as temperature and atmospheric composition, which are of great interest for studying the temporal evolution of climate and the composition of the remote atmosphere. Ideal conditions are found in central Antarctic regions where the very low temperatures and accumulation rates enable the formation of reliable atmospheric records spanning several hundred millennia. On the other hand, the meteorological and geographical conditions are generally less favorable at mid or low latitudes: ice-covered areas are much smaller, ice-flow patterns are frequently intricate (which makes ice-core dating uncertain) and overall higher temperatures are the cause of a more or less pronounced melting phenomenon which may perturb significantly the information contained in the deposited snow layers. Nevertheless, two of the longest non-polar isotope and chemical parameter records were obtained from temperate glaciers: Quelccaya Ice Cap (Thompson and others, 1988) and Vernagtferner (Baker and others, 1985). These limitations, in addition to the practical difficulties of working at very high altitudes, may explain why glacio-chemical data from high mountainous areas of the world are scarce, even though such research is strongly encouraged by scientific committees (e.g. SCAR (1974), for the Patagonian ice caps) dealing with regional or global climatic and environmental problems. The environmental data available for mid- and low-latitude glaciers have been reviewed recently by Wagenbach (1989).

In spite of the fact that the Patagonian ice caps are the most extensive non-polar ice caps $\left(18000 \mathrm{~km}^{2}\right.$; Fig. 1), they have been poorly studied in the past, in particular regarding glaciology and atmospheric chemistry. Little is known of the snow-accumulation rates in the area, the ice-cap thickness, the temperature or the movement of the ice. The chemical composition of the local precipitation has never been determined. The only relevant investigations presently published are those of Nakajima (1985) and Japanese Society of Snow and Ice (1987) on the northern Patagonia ice cap. A $37.5 \mathrm{~m}$ firn core was drilled in 1985 (Yamada, 1987), but unfortunately at a site where high melting and frequent rain events prevent any use of the ice samples for further isotopic and chemical investigations.

The purpose of this preliminary study is to document some of the parameters listed above in order to evaluate the feasibility of a more complete investigation of the area in the future, primarily based on a deep ice core which could be drilled on the southern Patagonia ice cap (SPIC), which is considered to be more suitable for such studies than the northern ice cap.

We report in this paper the analysis of a $13.17 \mathrm{~m}$ deep firn core drilled on the SPIC on 9 September 1986. This is the most recent ice core available in this region.

\section{SAMPLING CONDITIONS AND LABORATORY ANALYTICAL METHODS}

\section{Field work}

The SPIC, about $350 \mathrm{~km}$ long and $30-40 \mathrm{~km}$ wide, is situated between $48^{\circ} 20^{\prime}$ and $51^{\circ} 30^{\prime} \mathrm{S}$ and $73^{\circ}$ and $74^{\circ} \mathrm{W}$. 


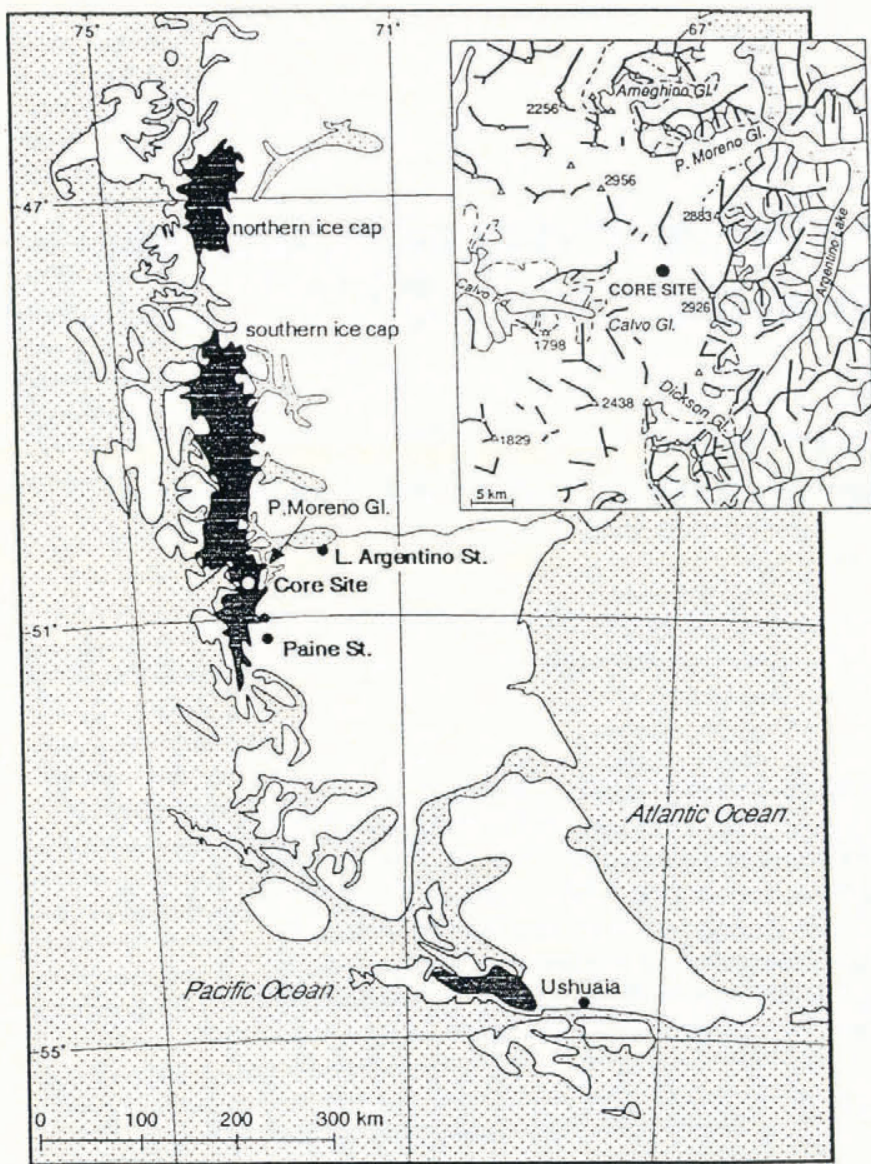

Fig. 1. Map of the southern part of the South American continent showing the two Patagonian ice caps. The study area is given in the inset (cartography by Lliboutry, 1981).

The drilling site $\left(50^{\circ} 38^{\prime} \mathrm{S}, 73^{\circ} 15^{\prime} \mathrm{W}, 2680 \mathrm{~m}\right.$ a.s.l. $)$ was located on a $100 \mathrm{~km}^{2}$ gently sloping plateau, which is the accumulation area for several large glaciers (Fig. 1). The sampling equipment, in particular the hand auger, and the operators were transported by helicopter from the edge of one of these glaciers (Perito Moreno). The firn core, placed immediately in an insulated box after drilling, was rapidly transferred to a freezer installed in a tourist bungalow located in the vicinity of the glacier. The temperature was measured at the bottom of the borehole $48 \mathrm{~h}$ after recovery of the firn core with the aid of a calibrated thermistor.

The firn core was cut into 45 sections at the bungalow. After density measurements, the core sections were subsampled for further isotope determinations. For chemical studies, the external part of each sample was removed using pre-cleaned tools by operators wearing clean-room clothes and masks. The firn samples were then transferred into sealed polyethylene bags and kept frozen until their analysis in Grenoble.

\section{Laboratory work}

The samples were analyzed in the laboratory in clean-air conditions, according to the procedure of Legrand and Delmas 1987). Major ions were determined by ion chromatography (Dionex 2010). The estimated precision was $10 \%$. The stable-isotope content $(\delta \mathrm{D} \%$ ) was measured by mass spectrometry on the sub-samples collected in the field at Centre d'Etudes Nucléaires de Saclay, France.

\section{RESULTS AND DISCUSSION}

\section{Temperature}

The temperature measured at the bottom of the borehole $(13.17 \mathrm{~m})$ was exactly $0^{\circ} \mathrm{C}$, indicating a temperate glacier. The mean annual temperature of the area, even at lower altitudes, is very poorly documented. We estimated the mean annual temperature at the drilling site tentatively using data collected at the meteorological stations of Lago Argentino $\left(50^{\circ} 20^{\prime} \mathrm{S}, 72^{\circ} 18^{\prime} \mathrm{W}, 200 \mathrm{~m}\right.$ a.s.l.), about $80 \mathrm{~km}$ to the northeast, and Torres del Paine $\left(51^{\circ} 10^{\prime} \mathrm{S}\right.$, $72^{\circ} 18^{\prime} \mathrm{W}, 125 \mathrm{~m}$ a.s.l.), about $60 \mathrm{~km}$ to the southsoutheast. The mean annual temperatures there were $7.3^{\circ} \mathrm{C}$ (Servicio Meteorológico Nacional de la República Argentina) and $7^{\circ} \mathrm{C}$ (personal comunication from W. C. Keene), respectively. The altitudinal temperature lapse rate used in the calculation is $0.53^{\circ} \mathrm{C} / 100 \mathrm{~m}$. This value, which is very close to the net adiabatic lapse rate, was obtained by Inoue and others (1987) for the northern Patagonia ice cap. The temperature calculated in this way is approximately $-6^{\circ} \mathrm{C}$, a figure relatively low in comparison with the Quelccaya Ice Cap $\left(-3^{\circ} \mathrm{C}\right)$, which prevents excessive percolation.

\section{Density}

The physical appearance of the shallow snow layers is typical of a temperate glacier, with coarse grains and numerous ice layers $0.5-30 \mathrm{~mm}$ thick. Consequently, the density $(d)$ profile is irregular, which is also characteristic of temperate glaciers. It can be represented by the linear regression $\left(R^{2}=0.78\right)$ of the 37 levels measured: $d=20 z+406\left(d\right.$ in $\mathrm{kg} \mathrm{m}^{-3}$ and $z$ in $\left.\mathrm{m}\right)$. The mean value $\left(606 \mathrm{~kg} \mathrm{~m}^{-3}\right)$ at $10 \mathrm{~m}$ depth and the transition depth of firn to ice (20-25 m, by extrapolation) are comparable to corresponding values obtained on the Quelccaya Ice Cap (64Q $\mathrm{kg} \mathrm{m}^{-3}$; Thompson, 1980) and on Vernagtferner $\left(640 \mathrm{~kg} \mathrm{~m}^{-3}\right.$ and $20-25 \mathrm{~m}$; Oerter and others, 1983). Similar values were also obtained on the northern Patagonia ice cap (Yamada, 1987), despite the different densification process due to the large amount of water present in the snow.

\section{Isotope measurements, dating and snow-accumul- ation rate}

The isotopic composition ( $\mathrm{O}$ and $\mathrm{H}$ atoms) of polar snow depends on atmospheric temperature (Dansgaard, 1964). Temperature changes, in particular seasonal cycles, are therefore naturally recorded in polar ice caps. These seasonal variations are commonly used for dating firn and ice layers (Hammer, 1989). On the other hand, for glaciers located at mid or tropical latitudes, meltwater percolation tends to destroy seasonal patterns and to homogenize the isotopic composition. For temperate glaciers, the effect is particularly well marked, and only in special cases (conjunction of particular meteorological and physical conditions) do the isotopic profiles still 


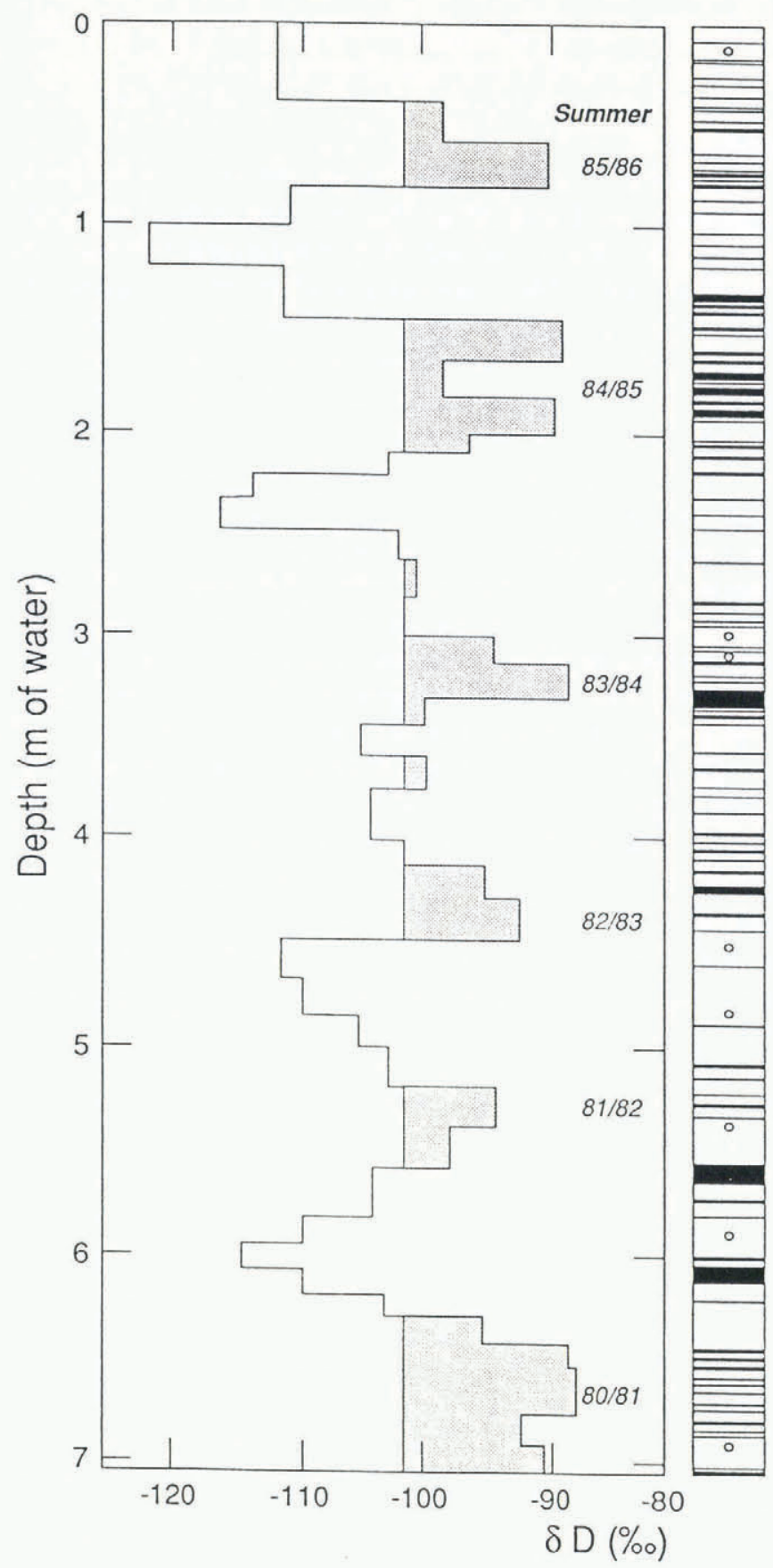

Fig. 2. Seasonal variations of the deuterium content compared with the snow stratigraphy. Water-equivalent depth ( $7.07 \mathrm{~m}$ at the bottom) is calculated using the mean density profile. Black segments represent ice layers (0.5$30 \mathrm{~mm}$ thick). Open circles represent ice lenses.

contain information usable for climatic and dating purposes (Stichler and others, 1983; Thompson and others, 1984). At our site, the relatively low estimated mean annual temperature $\left(-6^{\circ} \mathrm{C}\right)$ and local meteorological conditions (high precipitation rate, prevailing westerly Pacific winds and frequent cloudiness which reduced summer melting) are favourable factors for the preservation of the initial stratification of the snow layers. The isotopic profile (Fig. 2) exhibits fluctuations which can reasofably be attributed to seasonal variations. The core was dated on the basis of the visual glaciological stratigraphy reported in Figure 3, combined with the interpretation of this isotope profile. The winters of 1982 , 1984, 1985 and 1986 (date of field work) and the summers of 1980-81, 1983-84, 1984-85 and 1985-86 are clearly identified.

A mean value of $1.2 \mathrm{~m}$ water equivalent (w.e.) is deduced for the annual accumulation rate. This is only one-third of what can be expected from data obtained at nearby temporary stations (Agua y Energía, 1978) using their precipitation versus longitude gradient. Such a difference, also observed on the northern Patagonia ice cap (Fujiyoshi and others, 1987; Yamada, 1987), could be caused by the strong and frequent winds prevailing in the area (which blow away snow layers) and/or by some surface melting. This second explanation is less likely because of the absence of significant percolation patterns, as mentioned earlier. Finally, we cannot entirely rule out an erroneous interpretation of the annual signals, which could lead to a smaller value for the number of years encompassed by this core due, for instance, to the occurrence of two isotope peaks per year as is sometimes observed (for example, at Mont Blanc by Jouzel and others (1984)).

\section{Chemical measurements}

In temperate glaciers, the depth profiles of chemical species are generally significantly disturbed by meltwater percolation. When a water table forms, most of the soluble impurities are washed out and seasonal variations may be replaced by other fluctuations linked with the up and down movement of the water level. No information is available on whether this phenomenon occurs in the deeper firn layers. In the upper firn layers, a memory of the initial seasonal variations can persist for several years, provided percolation is not too intense. This seems to be the case at the study site, according to visual observations in the field (the ice core was "dry" and the borehole free of water) and to the persistence of the seasonal isotopic patterns.

Chemical depth profiles are shown in Figure 3. Suphate and nitrate concentrations both exhibit a rapid decrease (by more than 50\%) in the first $3 \mathrm{~m}$ (i.e. about 2 years). This part of the profile can be represented satisfactorily by exponential functions with $r^{2}=0.68$ and 0.66 for $\mathrm{SO}_{4}{ }^{2-}$ and $\mathrm{NO}_{3}{ }^{-}$, respectively. The ratio $\mathrm{Cl}^{-} / \mathrm{Na}^{+}$is 1.13 for the first year of accumulation, a value very close to the marine reference value (1.16). This observation is in agreement with the marine origin of the air masses in the area, as was also found at Torres del Paine (Table $1 ; \mathrm{Cl}^{-} / \mathrm{Na}^{+}=1.17$ ). However, this ratio decreases'markedly as a function of depth (Fig. 3), which indicates that $\mathrm{Cl}^{-}$is preferentially eluted to $\mathrm{Na}^{+}$. Below a depth of $3 \mathrm{~m}$, nitrate values continue to decrease, but more slowly, whereas sulphate values remain relatively stable around $0.4 \mu \mathrm{eq} .1^{-1}$. For $\mathrm{Cl}^{-}$and $\mathrm{Na}^{+}$, the decrease is much less marked and high values are still observed after 4 or 5 years. The $\mathrm{K}^{+}$and $\mathrm{NH}_{4}{ }^{+}$profiles appear to be independent of depth.

We can therefore conclude that the following elution sequence is obtained:

in agreement with the results of Davies and others (1982), which concerned a site where percolation was so high that the chemical impurities were removed after a single year. In our case, as indicated by the mean value of the $\mathrm{Cl}^{-} /$ $\mathrm{Na}^{+}$ratio, little loss of solute occurred in the upper part 


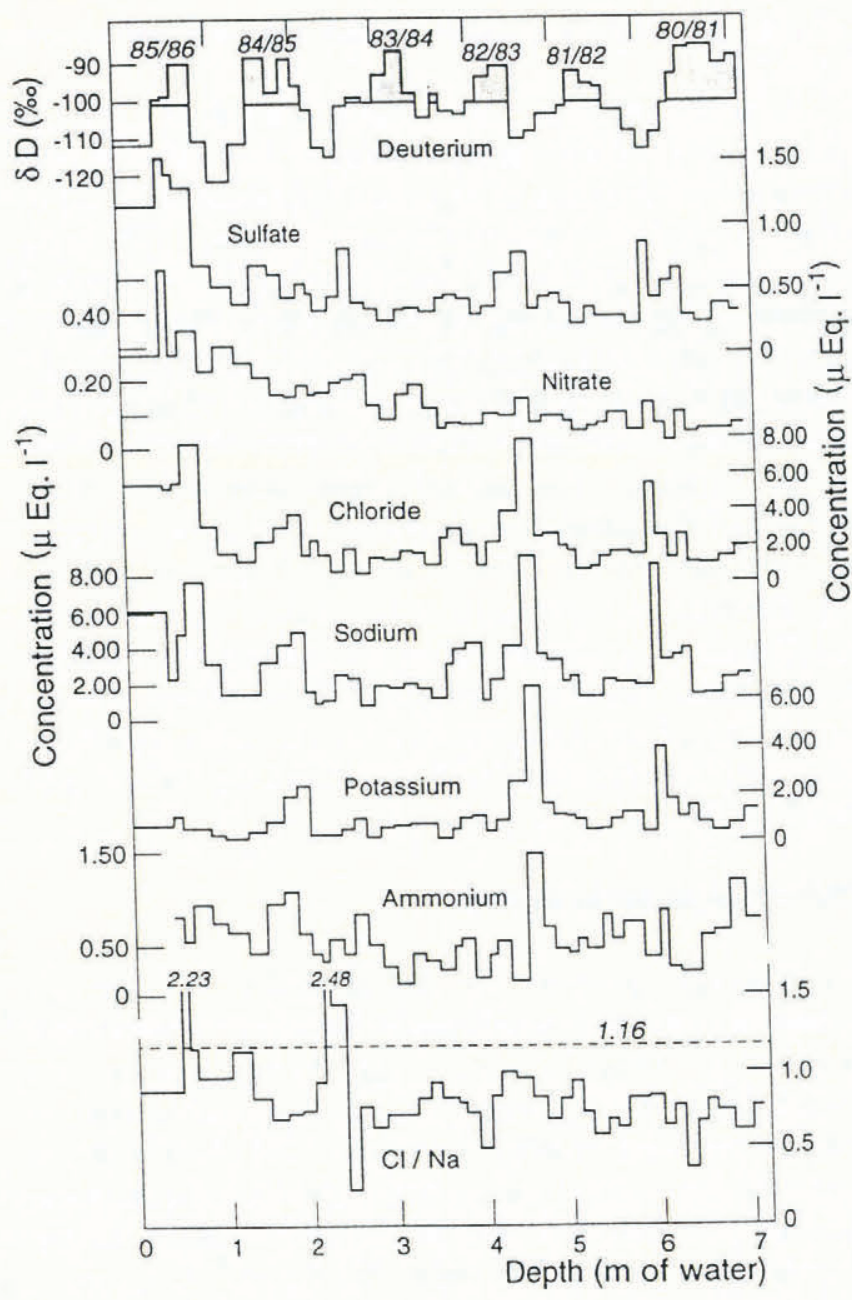

Fig. 3. Concentration profiles of the various ions determined in the firn core and $\mathrm{Cl} / \mathrm{Na}^{+}$ratio as a function of depth. The time-scale is given by the isotope profile (upper curve).

(mainly winter snowfall) of the firn. Thereafter, the concentrations of most elements are markedly disturbed by percolation and cannot be used as reliable atmospheric records.

We have therefore decided to consider only the last year of precipitation (six samples, from the winter of 1985 to the winter of 1986) as being representative of the actual levels of chemical impurities in the local precipitation, bearing in mind, however, that these values are possibly only lower bounds. These data are compared to the measurements at Torres del Paine (Likens and others, 1987), which is the closest station with existing precipitation chemical data (Table 1). All concentrations, except for $\mathrm{NH}_{4}{ }^{+}$, are lower at our southern Patagonia site than at the Torres del Paine site (as shown by the SPIC/ PAINE ratios for $\mathrm{Na}^{+}: 0.23, \mathrm{Cl}^{-}: 0.22, \mathrm{nssSO}_{4}{ }^{2-}: 0.31$, $\mathrm{NO}_{3}{ }^{-}: 0.64$ and $\mathrm{K}^{+}: 0.46$ ), in agreement with the large elevation difference between the two sites.

Nevertheless, potassium concentrations are relatively high on the southern Patagonia ice cap, in comparison with what might be expected from the marine source. Note that the $\mathrm{K}^{+} / \mathrm{Na}^{+}$ratio $(0.15)$ reported in Table 1 is significantly higher than both the marine reference ratio (0.023) and the ratio reported for Torres del Paine precipitation (0.07). Excess potassium could be linked to either a local crustal source or a contribution by vegetation. In the absence of calcium data, it is difficult to favour one of these hypotheses, even if the second appears to be less likely due to the paucity of vegetation in these areas.

A further comparison with the concentrations obtained on James Ross Island, Antarctic Peninsula (elevation $1640 \mathrm{~m}$ ), reveals that gas-derived compounds (nssSO ${ }_{4}^{2-}$ and $\mathrm{NO}_{3}^{-}$) have very similar concentrations on both ice caps, which could therefore be considered as representing background reference values for the mid to high latitudes in the southern Pacific Ocean.

These latitudes are very remote from large populated, industrial or agricultural centres. Anthropogenic sulphur and nitrogen compound levels are very low there as the atmosphere is constantly cleaned by heavy rains. It can therefore be assumed that the concentrations of gasderived aerosol or gases (excess $\mathrm{SO}_{4}{ }^{2-}$ and $\mathrm{NO}_{3}{ }^{-}$) are representative of the natural levels of freshly formed sulphate aerosol and gaseous $\mathrm{HNO}_{3}$, or from aged compounds transported in the free troposphere.

Our results at this location cover a very limited time period and it is difficult to evaluate what happens deeper in the glacier. We can only refer to the two temperate deep ice cores recovered from the Quelccaya Ice Cap (about $1.5 \times 10^{3}$ year; Thompson and others, 1986, 1988), where a useful conductometric profile was obtained, and to northern Spitsbergen, where $\mathrm{pH}$ and conductivity measurements cover possibly 6000 years (Fujii and others, 1990). Punning and others (1986) claimed they observed seasonal $\mathrm{Cl}^{-}$variations at considerable depths in Nordaustlandet, Svalbard.

\section{CONGLUSION}

The most important physical and chemical parameters relevant to past climate and environmental studies have been determined for the upper part of the temperate southern Patagonia ice cap. Although ice melting prevents the preservation of the initial atmospheric parameters below the surface layers, $\delta \mathrm{D}$ seasonal variations, preserved down to $10 \mathrm{~m}$ depth, combined with visual stratigraphy, allow the dating of the first five annual snow layers. Most measured chemical species exhibit a sharp decrease in concentration after about 1 year. The mean concentrations obtained from the last year of accumulation (winter 1985 to winter 1986) may serve as a reference for the chemical composition of precipitation at these latitudes, where South Pacific meteorological conditions prevail.

Such glaciological characteristics are apparently inadequate for long-term palaeoenvironmental studies. Nevertheless, we can reasonably expect that insoluble atmospheric impurities like crustal dust, soot particles or volcanic ash may well be preserved satisfactorily in deeper firn and ice layers (as demonstrated convincingly by the deep ice-core study reported by Thompson and others (1986, 1988) for the Quelccaya Ice Cap), making this ice cap a potential site for obtaining records of these important atmospheric tracers over several centuries. Little is known about the environmental history of these latitudes on such a time-scale. A deep ice core drilled at this location would be most valuable for documenting the 
Table 1. Chemical concentrations $\left(C, \mu e q . I^{-1}\right)$ and deposition fluxes $\left(\Phi, \mu M m^{-2} a^{-1}\right)$ in snow at the study site (southern Patagonia ice cap). The values are mean values obtained from the six shallowest samples (about 1 year of precipitation, see text). Precipitation chemistry data from Torres del Paine precipitation station $\left(51^{\circ} 10^{\prime} \mathrm{S}, 72^{\circ} 58^{\prime} \mathrm{W}\right.$, $125 \mathrm{~m}$ a.s.l.; Likens and others, 1987) and from James Ross Island, Antarctic Peninsula (mean values over 130 years; Aristarain and others, unpublished), are also reported for comparison. Corresponding deposition fluxes ( $\Phi)$ are calculated using the water-deposition rates $R_{\mathrm{w}}$ ( $m$ of water $a^{-1}$ )

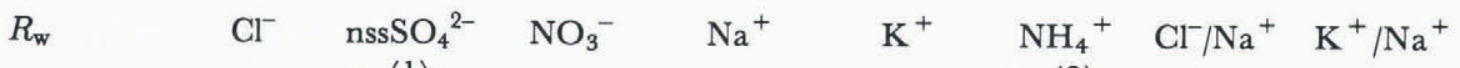

(1) (2)

\begin{tabular}{|c|c|c|c|c|c|c|c|c|c|c|}
\hline \multirow{2}{*}{$\begin{array}{l}\text { Southern } \\
\text { Patagonia ice } \\
\text { cap (SPIC) }\end{array}$} & \multirow[t]{2}{*}{$\begin{array}{c}1.20 \\
(3)\end{array}$} & C & 4.85 & 0.65 & 0.32 & 4.30 & 0.64 & 0.77 & \multirow[t]{2}{*}{1.13} & \multirow[t]{2}{*}{0.15} \\
\hline & & $\Phi$ & 5820 & 390 & 384 & 5160 & 768 & 924 & & \\
\hline Torres del & & C & 21.9 & 2.1 & 0.5 & 18.7 & 1.4 & 0.7 & 1.17 & 0.07 \\
\hline Paine (TP) & $\begin{array}{c}0.75 \\
(4)\end{array}$ & $\Phi$ & 16425 & 787 & 375 & 14025 & 1050 & 525 & & \\
\hline James Ross & & $\mathrm{C}$ & 7.17 & 0.68 & 0.33 & ND & ND & & & \\
\hline $\begin{array}{l}\text { Island (Antarc- } \\
\text { tic Peninsula) }\end{array}$ & $\begin{array}{c}0.59 \\
(5)\end{array}$ & $\Phi$ & 4237 & 201 & 195 & & & & & \\
\hline$\Phi_{\mathrm{TP}} / \Phi_{\text {SPIC }}$ & & & 2.82 & 2.02 & 0.98 & 2.72 & 1.37 & 0.57 & & \\
\hline
\end{tabular}

(1) $\mathrm{nssSO}_{4}{ }^{2-}$ (non-sea-salt sulphate) was calculated as follows from measured sulphate $\left(\mathrm{SO}_{4}{ }^{2-}\right):\left[\mathrm{nssSO}_{4}{ }^{2-}\right]$

$=\left[\mathrm{SO}_{4}{ }^{2-}\right]-0.104\left[\mathrm{Cl}^{-}\right]$, where 0.104 is the reference value of the ratio $\left[\mathrm{SO}_{4}{ }^{2-}\right] /\left[\mathrm{Cl}^{-}\right]$in bulk sea water.

(2) For ammonium, the value of the shallowest sample was excluded because of contamination.

(3) This work.

(4) W. C. Keene (personal communication).

(5) Aristarain and others, 1987.

ND Not determined.

past (e.g. climate fluctuations, volcanic eruptions) of this remote part of the Southern Hemisphere.

\section{AGKNOWLEDGEMENTS}

J.C. Tretrop and V.H. Videla are gratefully acknowleged for their help in the field. Logistic support was provided by Gendarmería Nacional Argentina, Escuadrones Calafate and Río Gallegos. We thank helicopter pilots A.S. González and J. Medina, P. Yankelevich (National Park, Calafate), J. L. Barral (Agent of Hostería Ventisquero P. Moreno) and E. Mayor, of Santa Cruz Province. We are indebted to Dr W. C. Keene (Department of Environmental Sciences, University of Virginia, Charlottesville, U.S.A.) for data concerning Torres del Paine station. Financial support was provided in Argentina by Instituto Antártico Argentino and Consejo Nacional de Investigaciones Científicas y Técnicas, Buenos Aires, and by the Government of Santa Cruz Province in Río Gallegos (we thank particularly Mrs A. Esquivel of the planning service), and in France by Centre National de la Recherche Scientifique, Ministry of Foreign Affairs and the Commissariat à l'Energie
Atomique. This paper was written during the stay of one of the authors (A.J.A.) in France in the framework of a Commission of European Community Marie-Curie Fellowship.

\section{REFERENGES}

Agua y Energía Eléctrica. 1978. Informe sobre precipitaciones y balance hidrológico. Estudio del río Santa Cruz en relación con su aprovechamiento hidroeléctrico integral. Agua y Energía Eléctrica de la República Argentina. (Plano SZ-Q-004.)

Aristarain, A.J., J.F. Pinglot and M. Pourchet. 1987. Accumulation and temperature measurements on the James Ross Island ice cap, Antarctic Peninsula, Antarctica. 7. Glaciol., 33(115), 357-362.

Baker, D., H. Moser, H. Oerter, W. Stichler and O. Reinwarth. 1985. Comparison of the ${ }^{2} \mathrm{H}$ and ${ }^{18} \mathrm{O}$ content of ice cores from a temperate Alpine glacier (Vernagtferner, Austria) with climatic data. Z. Gletscherkd. Glazialgeol., 21, 389-395.

Dansgaard, W. 1964. Stable isotopes in precipitation. Tellus, 16(4), 436-468. 
Davies, T. D., C. E. Vincent and P. Brimblecombe. 1982. Preferential elution of strong acids from a Norwegian ice cap. Nature, 300(5888), 161-163.

Fujii, Y. and 10 others. 1990. 6000-year climate records in an ice core from the Høghetta ice dome in northern Spitsbergen. Ann. Glaciol., 14, 85-89.

Fujiyoshi, Y., H. Kondo, J. Inoue and T. Yamada. 1987. Characteristics of precipitation and vertical structure of air temperature in the northern Patagonia. Bull. Glacier Res. 4, 15-23.

Hammer, C. U. 1989. Dating by physical and chemical seasonal variations and reference horizons. In Oeschger, H. and C. C. Langway, Jr, eds. The environmental record in glaciers and ice sheets. Chichester, etc., John Wiley and Sons, 99-121.

Inoue, J., H. Kondo, Y. Fujiyoshi, T. Yamada, H. Fukami and C. Nakajima. 1987. Summer climate of the northern Patagonia icefield. Bull. Glacier Res. 4, 714.

Japanese Society of Snow and Ice. 1987. Bulletin for Glacier Research No. 4. Tokyo, Japanese Society of Snow and Ice. Data Center for Glacier Research.

Jouzel, J., M. R. Legrand, J. F. Pinglot, M. Pourchet and L. Reynaud. 1984. Chronologie d'un carottage de $20 \mathrm{~m}$ au Col du Dôme (Massif du Mont-Blanc). Houille Blanche, 6, 491-497.

Legrand, M. R. and R.J. Delmas. 1987. Experimental protocol for the chemical analysis of snow, firn and ice cores. In Jones, H. G. and W.J. Orville-Thomas, eds. Seasonal snowcovers: physics, chemistry, hydrology. Dordrecht, etc., D. Reidel Publishing Co., 225-254.

Likens, G.E., W. C. Keene, J.M. Miller and J.N. Galloway. 1987. Chemistry of precipitation from a remote, terrestrial site in Australia. 7. Geophys. Res., 92(D11), 13,299-13,314.

Lliboutry, L. 1981. Mapas esquemáticos de los campos de hielo de Patagonia y Tierra del Fuego al 1/500.000. St Martin d'Hères, Laboratoire de Glaciologie et Géophysique de l'Environnement (CNRS). (Publication 532.)

Nakajima, C., ed. 1985. Glaciological studies in Patagonia northern icefield 1983-1984. Tokyo, Japanese Society of Snow and Ice. Data Center for Glacier Research.
Oerter, H., O. Reinwarth and H. Rufli. 1983. Core drilling through a temperate Alpine glacier (Vernagtferner, Oetztal Alps) in 1979. Z. Gletscherkd. Glazialgeol., 18(1), 1982, 1-11.

Punning, Ya.-M.K., T. A. Martma, K. E. Tyugu, R.A. Vaykmyae, M. Pourchet and F. Pinglot. 1986. Stratification in an ice core from Vestfonna, Nordaustlandet. Polar Geogr. Geol., 10(1), 39-43.

SCAR. 1974. SCAR Bulletin. Report of the SCAR Executive Meeting, Cambridge, 9-11 July 1973. Polar Rec., 17(106), 79-99.

Stichler, W., D. Baker, H. Oerter and P. Trimborn. 1983. Core drilling on Vernagtferner (Oetztal Alps, Austria) in 1979: deuterium and oxygen-18 contents. $Z$. Gletscherkd. Glazialgeol., 18(1), 1982, 23-35.

Thompson, L. G. 1980. Glaciological investigations of the tropical Quelccaya ice cap, Peru. J. Glaciol., 25(91), 69-84.

Thompson, L. G., E. Mosley-Thompson, P. M. Grootes, M. Pourchet and S. Hastenrath. 1984. Tropical glaciers: potential for ice core paleoclimatic reconstructions. 7. Geophys. Res., 89(D3), 4638-4646.

Thompson, L. G., E. Mosley-Thompson, W. Dansgaard and P.M. Grootes. 1986. The Little Ice Age as recorded in the stratigraphy of the tropical Quelccaya ice cap. Science, 234(4774), 361-364.

Thompson, L. G., M. E. Davis, E. Mosley-Thompson and K-b. Liu. 1988. Pre-Incan agricultural activity recorded in dust layers in two tropical ice cores. Nature, 336(6201), 763-765.

Wagenbach, D. 1989. Environmental records in alpine glaciers. In Oeschger, H. and C. C. Langway, Jr, eds. The environmental record in glaciers and ice sheets. Chichester, etc., John Wiley and Sons, 69-83.

Yamada, T. 1987. Glaciological characteristics revealed by 37.6-m deep core drilled at the accumulation area of San Rafael Glacier, the northern Patagonia icefield. Bull. Glacier Res. 4, 59-67.

The accuracy of references in the text and in this list is the responsibility of the authors, to whom queries should be addressed. 